\title{
POTENSI PENCEMARAN LIMBAH INDUSTRI TERHADAP KESEHATAN MASYARAKAT DAN BIOTA AIR DI WILAYAH PESISIR CILEGON
}

\author{
Ja'far Salim \\ Fakultas Teknik, Universitas Sultan Ageng Tirtayasa \\ Email: jafarsalim@ft-untirta.ac.id
}

\begin{abstract}
ABSTRAK
Banyak wilayah pesisir di dunia, termasuk Indonesia telah mengalami tekanan ekologi yang semakin parah dan kompleks, apakah itu polusi, degradasi fisik habitat pesisir, serta konflik ruang dan penggunaan sumber daya. Tujuan dari penelitian ini adalah: mengidentifikasi jenis penyakit pada populasi industri; menentukan kualitas air laut di pesisir dan mengetahui standar kualitas logam berat pada biota di perairan pesisir. Hasil dari penelitian ini adalah: semakin jauh lokasi industri, maka jumlah komunitas yang terkena penyakit rendah, hal ini disebabkan semakin jauh dari lokasi polusi udara industri, sehingga mempengaruhi semakin rendah polusi udara rendah, limbah industri menjadi kriteria limbah B3, tetapi tidak mengakibatkan kualitas air laut yang buruk di wilayah pesisir Cilegon sehingga masih semua dalam batas aman dan tidak melewati baku mutu air laut; konsentrasi logam berat dalam sedimen dan kerang cukup tinggi sehingga $\mathrm{Pb}$ dalam insang mencapai $87 \mathrm{ppm}$, sedangkan hati (hepatopancreas) mencapai 97 ppm. Konsentrasi Cd di insang mencapai 69 ppm, sedangkan hati mencapai 171 ppm. Konsentrasi $\mathrm{Cr}$ dalam insang mencapai 13.3 ppm, sedangkan hati mencapai 75.64 ppm. Konsentrasi $\mathrm{Hg}$ dalam insang mencapai 69 ppm, sedangkan hati mencapai 121.52 ppm.
\end{abstract}

Kata kunci: limbah Industri, jenis penyakit, kualitas standar, logam berat, wilayah pesisir

\section{POTENTIAL OF INDUSTRIAL WASTE POLLUTION ON COMMUNITY HEALTH AND aquatic biota IN THE COASTAL AREAS OF CILEGON}

\author{
Ja'far Salim \\ Faculty of Engineering, Sultan Ageng Tirtayasa University \\ Email: jafarsalim@ft-untirta.ac.id
}

\begin{abstract}
Many coastal areas in the world, including Indonesia has experienced an increasingly severe ecological pressures and complex, whether it be pollution, physical degradation of coastal habitats, as well as space and resource use conflicts. The purpose of this research are: identify the types of diseases in the industrial population; determining the quality of sea water in coastal and knowing the quality standards of heavy metals on biota in the coastal water. The results of this study are: the more distant industrial sites, then the number of communities affected by the disease is low, this is due to more distant from the location of the industrial air pollution, thus affecting more and more low low air pollution, industrial waste into the B3 waste criteria, but did not result in bad quality of seawater in coastal areas Cilegon so it is still all within the secure and not passed the sea water quality standard; concentration of heavy metals in sediments and shellfish is high enough that the $\mathrm{Pb}$ in the gills reached $87 \mathrm{ppm}$, whereas the liver (hepatopancreas) reached $97 \mathrm{ppm}$. Cd concentration in the gills reached $69 \mathrm{ppm}$, whereas the liver reaches $171 \mathrm{ppm}$. Cr concentration in the gills reached $13.3 \mathrm{ppm}$, whereas the liver reaches 75.64 ppm. $\mathrm{Hg}$ concentrations in the gills reached $69 \mathrm{ppm}$, whereas the liver reaches $121.52 \mathrm{ppm}$.
\end{abstract}

Keywords: Industrial waste, type of disease, standard quality, heavy metals, coastal region 


\section{PENDAHULUAN}

\subsection{Latar Belakang}

Banyak wilayah pesisir di dunia termasuk Indonesia telah mengalami tekanan ekologis yang semakin parah dan kompleks, baik berupa pencemaran, eksploitasi sumberdaya alam yang berlebihan dan pengikisan keanekaragaman hayati, degradasi fisik habitat pesisir, maupun konflik penggunaan ruang dan sumberdaya.2) Wilayah pesisir merupakan daerah peralihan antara ekosistem darat dan lautan, juga merupakan kawasan di permukaan bumi yang padat dihuni oleh umat manusia serta tempat berlangsungnya berbagai macam jenis kegiatan dalam pembangunan. Berbagai ekosistem dengan produktivitas hayati tertinggi, seperti satwa air, hutan mangrove, terumbu karang, dan estuaria, berada di wilayah pesisir. Sedangkan food and agriculture organization (FAO) pada 1992 menyatakan lebih dari 90\% total produksi perikanan dunia (sekitar 82 juta ton), baik melalui kegiatan penangkapan maupun budidaya berasal dari wilayah pesisir (Clark, J.R. 1992).

Kemajuan di bidang industri di masa sekarang ini mengakibatkan banyaknya aktivitas manusia di darat yang menyebabkan tekanan terhadap pertanian sekitarnya meningkat. Pertambahan jumlah industri dan penduduk membawa akibatnya bertambahnya beban pencemaran yang disebabkan oleh pembuangan limbah industri dan domestik. Pencemaran tersebut menyebabkan kerugian besar karena umumnya limbah mengandung zat beracun antara lain klor, raksa, kadmium, khrom, timbal, dan lain sebagainya yang sering digunakan dalam proses produksi suatu industri, baik sebagai bahan baku, katalisator atau bahan utama (Rochyatun, E., Lestari, A. Rozak. 2005). Hal tersebut karena paradigma dan pola pembangunan yang selama ini terlampau berorientasi pada pertumbuhan ekonomi, tanpa adanya perhatian yang memadai terhadap karakteristik, fungsi, dan dinamika ekosistem wilayah pesisir yang menyusun daya dukung dan kapasitas ekosistem ini bagi kelangsungan pembangunan, maka dikawatirkan akan terjadi pencemaran lingkungan di wilayah pesisir.

Sementara itu, di beberapa wilayah pesisir tingkat kerusakan ekologis tersebut telah mencapai atau melampaui daya dukung lingkungan dan kapasitas keberlanjutan (sustainable capacity) dari ekosistem wilayah pesisir untuk menopang kegiatan pembangunan dan kehidupan manusia di masa mendatang. Salah satu pencemaran lingkungan pesisir adalah masuknya logam berat di perairan. Peningkatan kadar logam berat di dalam perairan akan diikuti oleh peningkatan kadar zat tersebut dalam organisme air seperti kerang, ikan, rumput laut dan biota laut lainnya. Akibatnya lingkungan menjadi salah satu sasaran pencemaran, terutama sekali lingkungan perairan yang sudah pasti terganggu oleh adanya limbah industri, baik industri pertanian maupun industri pertambangan. Sebagian besar dari limbah itu biasanya dibuang begitu saja tanpa pengolahan terlebih dahulu.

Adanya kontaminan logam berat di tanah yang berasal dari lumpur (sludge) mendorong peningkatan akumulasi kandungan logam berkorelasi positif dengan dosis lumpur, ${ }^{5)}$ sedangkan peningkatan akumulasi logam $\mathrm{Pb}$ dan $\mathrm{Cd}$ di dalam lumpur (sludge) mengalami mobilisasi dan ditranslokasikan ke kawasan sekitarnya (Sukreeyapongse, O, et al., 2002). Hal ini juga dapat menghambat perbaikan lingkungan yang rusak akibat pencemaran air limbah yang mengalir di lingkungan sekitarnya termasuk di wilayah pesisir Cilegon. Karena hal yang paling ditakutkan adalah menurunnya kualitas badan air penerima, karena sebagian besar bahan baku industri logam bersifat karsinogenik. Meskipun beberapa industri telah memiliki instalasi pengolahan air limbah (IPAL) namun pengolahannya diduga belum maksimal.

Badan Pusat Statistik (BPS) Kota Cilegon 5 tahun terakhir ini mencatat jumlah industri sebanyak 85 purusahaan swasta yang tumbuh dan berkembang di Kota Cilegon setiap tahun selalu bertambah, baik industri menengah maupun industri berat baik yang bergerak bidang pabrik baja, kimia, semen, gula dan sebagainya. Selain itu industri yang bergerak pada kelompok industri Krakatau sebanyak \pm 58 jenis perusahaan dengan berbagai jenis usaha di kawasan industri Cilegon.

Analisis pengelolaan limbah industri di wilayah pesisir Cilegon ditujukan untuk mengetahui hasil pengelolaan limbah, baik yang berkecenderungan terkena dampak pencemaran lingkungan yang disebabkan oleh aktivitasaktivitas pabrik yang beroperasi di wilayah tersebut.

\subsection{Tujuan Penelitian}

Berdasarkan latar belakang masalah tersebut, maka penelitian ini bertujuan untuk: (1) mengidentifikasi jenis penyakit penduduk di kawasan industri; (2) menentukan kualitas air laut di perairan/pesisir; dan (3) mengetahui baku mutu logam berat pada biota air di perairan/pesisir.

\section{METODE PENELITIAN}

Penelitian ini dilakukan di kawasan industri dan wilayah pesisir Cilegon yang berlokasi di empat kecamatan yaitu Kecamatan Ciwandan, Kecamatan Citangkil, Kecamatan Grogol, dan Kecamatan Pulomerak di Kota Cilegon. 


\subsection{Mengidentifikasi Potensi Jenis Penyakit}

Perkembangan pesat industri di Kota Cilegon saat ini tidak lain karena banyaknya investor yang menanamkan sahamnya di daerah yang sangat strategis dan menjanjikan dalam dunia usaha. Di sisi lain penerapan teknologi oleh perusahaan maupun manusia guna mendapatkan kualitas hidup yang lebih baik seringkali tidak diikuti oleh faktor keselamatan dan kesehatan kerja yang memadai, yang pada akhirnya berdampak pada kerusakan lingkungan dan kesehatan masyarakat sekitarnya. Berdasarkan data Dinas Kesehatan Kota Cilegon terdapat sepuluh besar jenis penyakit yang hampir ditemukan pada setiap kecamatan di empat kecamatan wilayah industri yaitu penyakit ISPA, tukak lambung, TBC paru BTA, dermatitis (penyakit kulit), myalgia (nyeri sendi), hypertensi esensial, diare \& gastroentiritis, artritis (radang), demam, dan gejala penyakit lainnya. Berdasarkan sepuluh jenis penyakit tersebut, selanjutnya dapat diidentifikasi menjadi empat jenis penyakit yang diakibatkan oleh pengaruh pencemaran limbah industri (polusi udara, air, dan tanah) di kawasan industri Kota Cilegon.

\subsection{Menentukan Kualitas Air Laut}

Menentukan kualitas air laut pada penelitian ini terutama kandungan logam beratnya, karena adanya logam berat di perairan berbahaya, baik secara langsung terhadap kehidupan organisme maupun efeknya secara tidak langsung terhadap kesehatan manusia. Hal ini berkaitan dengan sifat-sifat logam berat, yaitu:

a. Sulit didegradasi, sehingga mudah terakumulasi dalam lingkungan perairan dan keberadaannya secara alami sulit dihilangkan.

b. Dapat terakumulasi dalam organisme termasuk kerang dan ikan, dan akan membahayakan kesehatan manusia yang mengkomsumsi organisme tersebut.

c. Mudah terakumulasi di sedimen, sehingga konsentrasinya selalu lebih tinggi dari konsentrasi logam dalam air. Disamping itu sedimen mudah tersuspensi karena pergerakan air yang akan melarutkan kembali logam yang dikandungnya ke dalam air, sehingga sedimen menjadi sumber pencemar potensial dalam skala waktu tertentu.

\subsection{Menentukan Baku Mutu}

Menentukan baku mutu terhadap lingkungan ditujukan untuk mengetahui batas aman dari bahan yang membahayakan dalam pengelolaan limbah baja terhadap degradasi kelestarian wilayah pesisir atau terhadap ekosistem perairan dan kesehatan masyarakat. Batas aman disini apakah lingkungan masih dapat mentoleransi sehingga tidak terjadi akumulasi standar kualitas dan dapat dijadikan sebagai pembanding untuk mengetahui perubahan kualitas lingkungan. Tujuan dilakukan analisis baku mutu untuk: (1) keperluan pemantauan (monitoring), dan (2) pengendalian (controlling).

Di dalam penetapan baku mutu ini terdapat prinsip-prinsip yang dapat dilakukan yaitu: (1) tidak terlalu memberatkan pengusaha. (2) tidak mengabaikan kesehatan masyarakat. Sehingga diharapkan dalam penetapan baku mutu ini terjadi keseimbangan antara kepentingan pengusaha dengan lingkungan sekitarnya.

Adapun langkah-langkah teknik pendekatan penyusunan baku mutu adalah sebagai berikut:

a. Identifikasi dari penggunaan sumberdaya atau media ambien yang harus dilindungi.

b. Merumuskan formulasi dari kriteria dengan menggunakan kumpulan dan pengolahan dari berbagai informasi ilmiah.

c. Merumuskan baku mutu ambien (berkenaan dengan lingkungan) dari hasil penyusunan kriteria

d. Merumuskan baku mutu limbah yang boleh dikemas ke dalam lingkungan.

e. Membentuk program pemantauan dan pengumpulan berbagai informasi untuk penyempurnaan (Suratmo, F.G. 2002).

Sedangkan menurut Keputusan Menteri Negara Kependudukan dan Lingkungan Hidup Nomor: 03 tahun 1991 pasal 13 menyatakan untuk mencegah pembuangan kejutan (stock loading) pada sistem pengolahan limbah atau pada sumber air, setiap pabrik harus mengadakan suatu sistem dengan mencegah agar beban pencemaran limbah tidak boleh lebih tinggi $100 \%$ dari beban pencemaran cair rata-rata setiap bulan. Di dalam penelitian ini difokuskan pada pengambilan sampel sedimen dan biota air di wilayah pesisir Cilegon.

\section{Hasil dan Pembahasan}

\subsection{Potensi Jenis Penyakit}

Kota Cilegon memiliki 8 (delapan) kecamatan, namun dalam penelitian ini hanya 4 (empat) kecamatan yang secara geografis, keempat kecamatan ini merupakan wilayah industri yang meliputi: Kecamatan Ciwandan, Kecamatan Citangkil, Kecamatan Grogol dan Kecamatan Pulomerak. Mengingat penelitian dilakukan di kawasan industri Kota Cilegon, maka fokus penelitiannya ditujukan pada empat kecamatan tersebut terlihat pada Gambar 1. Dari keempat kecamatan tersebut, juga merupakan wilayah pesisir: 1). di Kecamatan Ciwandan meliputi: Desa Tegal Ratu, Desa Gunung Sugih, Desa Kepuh, Desa Randakari, dan Desa Kubang 
Sari; 2). di Kecamatan Citangkil meliputi Desa Warnasari, dan Desa Semang Raya, 3). di Kecamatan Pulomerak meliputi Desa Suralaya,
Desa Tamansari, Desa Mekarsari, dan Desa Lebak Gede; 4). di Kecamatan Grogol meliputi Desa Gerem, dan Desa Rawa Arum.

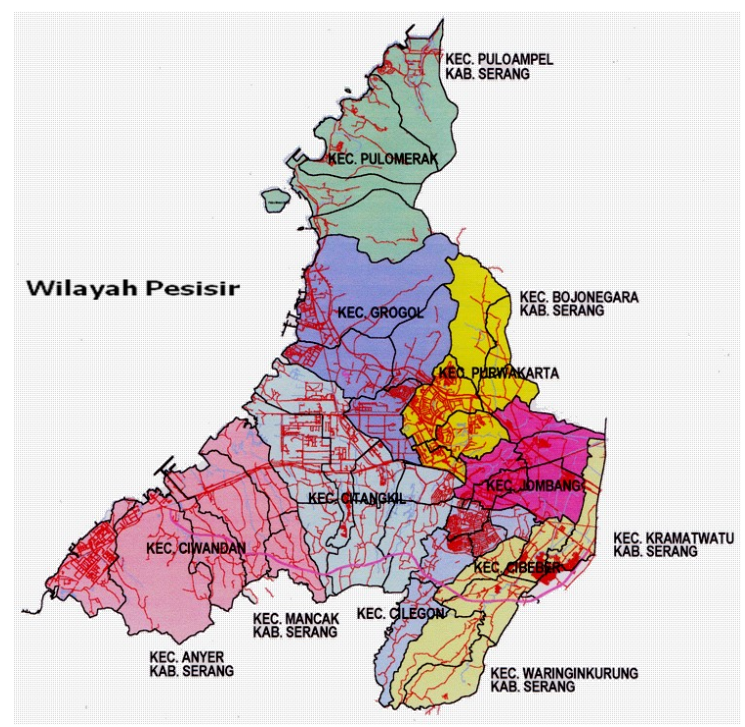

Gambar 1: Pesisir Kota Cilegon

Pada perkembangan industri di Kota Cilegon saat ini tidak lain karena banyaknya investor yang menanamkan sahamnya di daerah yang sangat strategis dan menjanjikan dalam dunia usaha. Di sisi lain penerapan teknologi oleh perusahaan maupun manusia guna mendapatkan kualitas hidup yang lebih baik seringkali tidak diikuti oleh faktor keselamatan dan kesehatan kerja yang memadai, yang pada akhirnya berdampak pada kerusakan lingkungan dan kesehatan masyarakat sekitarnya.

Berdasarkan data Dinas Kesehatan Kota Cilegon tahun 2005 - 2009 terdapat sepuluh besar jenis penyakit yang hampir ditemukan pada setiap empat kecamatan yang merupakan wilayah pesisir kawasan industri Cilegon, yaitu penyakit: ISPA, tukak lambung, TBC paru BTA, dermatitis (penyakit kulit), myalgia (nyeri sendi), hypertensi esensial, diare \& gastroentiritis, artritis (radang), demam, dan gejala penyakit lainnya. Berdasarkan sepuluh jenis penyakit tersebut, selanjutnya dapat diidentifikasi menjadi empat jenis penyakit yang diakibatkan oleh pengaruh pencemaran limbah industri (polusi udara, air, dan tanah) di Kota Cilegon. Namun pada penelitian, hanya mengidentifikasi jenis penyakit berkecenderungan jumlah penyakit paling besar di empat kecamatan Kota Cilegon' yaitu: penyakit ISPA, Dematitis, TBC Paru TBA, dan Artritis.

Selanjutnya untuk mengetahui hasil identifikasi potensi jenis penyakit dengan jumlah penduduk di tiap-tiap kecamatan wilayah pesisir Cilegon dapat diperlihatkan besaran persentasinya (\%) disajikan pada Tabel $1-4$.

Tabel 1: Persentasi potensi orang terkena penyakit tertentu di Kecamatan Ciwandan

\begin{tabular}{cccccccccccc}
\hline \multirow{2}{*}{ No. } & \multirow{2}{*}{ Uraian } & \multicolumn{7}{c}{ Persentasi (\%) Orang Terkena Penyakit Tertentu Di Kecamatan Ciwandan } \\
\cline { 2 - 12 } & $\mathbf{2 0 0 5}$ & $\mathbf{2 0 0 6}$ & $\mathbf{2 0 0 7}$ & $\mathbf{2 0 0}$ & $\mathbf{2 0 0 8}$ & $\mathbf{\%}$ & $\mathbf{2 0 0 9}$ & $\mathbf{\%}$ \\
\hline 1 & ISPA & 5.285 & 14,53 & 5.465 & 14,51 & 5.671 & 14,71 & 6.098 & 15,68 & 6.775 & 17,02 \\
\hline 2 & Dermatitis & 2.878 & 7,91 & 3.150 & 8,36 & 3.212 & 8,33 & 3.453 & 8,88 & 3.837 & 9,64 \\
\hline 3 & $\begin{array}{l}\text { TBC Paru } \\
\text { BTA }\end{array}$ & 1.485 & 4,08 & 1.658 & 4,40 & 1.890 & 4,90 & 2.032 & 5,22 & 2.258 & 5,67 \\
\hline 4 & $\begin{array}{l}\text { Artritis } \\
\text { lainnya }\end{array}$ & 1.160 & 3,19 & 1.285 & 3,41 & 1.301 & 3,37 & 1.399 & 3,60 & 1.554 & 3,90 \\
\hline 5 & Penduduk & 36.384 & & 37.65 & & 38.552 & & 38.898 & & 39.800 & \\
\hline
\end{tabular}

Berdasarkan Tabel 1 di atas menunjukaan persentasi potensi orang terkena penyakit ISPA $>14 \%$. Urutan berikutnya jenis penyakit berikutnya adalah penyakit dermatitis $>7 \%$ tahun 2005 - 2009, hal tersebut terjadi karena di
Kecamatan Ciwandan telah berdiri dan berkembangnya jumlah industri yang sangat pesat berkecenderungan terjadinya pencemaran lingkungan. 
Tabel 2: Persentasi potensi orang terkena penyakit tertentu di Kecamatan Citangkil

\begin{tabular}{cccccccccccc}
\hline \multirow{2}{*}{ No. } & \multirow{2}{*}{ Uraian } & \multicolumn{7}{c}{ Persentasi (\%) Orang Terkena Penyakit Tertentu Di Kecamatan Citangkil } \\
\cline { 2 - 12 } & $\mathbf{2 0 0 5}$ & $\mathbf{2 0 0 6}$ & $\mathbf{2 0 0 7}$ & $\mathbf{2 0}$ & $\mathbf{2 0 0 8}$ & $\%$ & $\mathbf{2 0 0 9}$ & $\%$ \\
\hline 1 & ISPA & 9.868 & 18,60 & 10.015 & 18,44 & 10.246 & 18,43 & 11.017 & 19,51 & 12.241 & 21,18 \\
\hline 2 & Dermatitis & 1.844 & 3,48 & 1.995 & 3,67 & 2.021 & 3,63 & 2.173 & 3,85 & 2.414 & 4,18 \\
\hline 3 & $\begin{array}{l}\text { TBC Paru } \\
\text { BTA }\end{array}$ & 925 & 1,74 & 997 & 1,84 & 1.045 & 1,88 & 1.123 & 1,99 & 1.248 & 2,16 \\
\hline 4 & $\begin{array}{l}\text { Artritis } \\
\text { lainnya }\end{array}$ & 985 & 1,86 & 1.056 & 1,94 & 1.211 & 2,18 & 1.302 & 2,31 & 1.447 & 2,50 \\
\hline 5 & Penduduk & 53.040 & & 54.299 & & 55.589 & & 56.472 & 57.782 & \\
\hline
\end{tabular}

Berdasarkan Tabel 2 di atas menunjukaan persentasi potensi orang terkena penyakit yang cukup tinggi, seperti halnya yang terjadi di Kecamatan Ciwandan. Di Kecamatan Citangkil jenis penyakit tertinggi adalah penyakit ISPA > $18 \%$ dan di kecamatan ini telah tumbuh dan berkembangnya sejumlah industri, baik industri menengah maupun industri berat yang berkecenderungan terjadinya pencemaran lingkungan sehingga jumlah penyakit ISPA tergolong sangat besar dari tahun 2005 - 2009, namun jenis penyakit lainnya masih tergolong normal.

Tabel 3: Persentasi potensi orang terkena penyakit tertentu di Kecamatan Grogol

\begin{tabular}{cccccccccccc}
\hline \multirow{2}{*}{ No. } & \multirow{2}{*}{ Uraian } & \multicolumn{7}{c}{ Persentasi (\%) Orang Terkena Penyakit Tertentu Di Kecamatan Grogol } \\
\cline { 3 - 13 } & $\mathbf{2 0 0 5}$ & $\mathbf{2 0 0 6}$ & $\mathbf{2 0 0 7}$ & $\mathbf{2 0 0 7}$ & $\mathbf{2 0 0 8}$ & $\mathbf{2 0}$ & $\mathbf{2 0 0 9}$ & \% \\
\hline 1 & ISPA & 2.468 & 8,01 & 2.505 & 7,94 & 2.664 & 8,25 & 2.865 & 8,72 & 3.183 & 9,47 \\
\hline 2 & Dermatitis & 590 & 1,91 & 611 & 1,94 & 624 & 1,93 & 671 & 2,04 & 745 & 2,22 \\
\hline 3 & $\begin{array}{l}\text { TBC Paru } \\
\text { BTA }\end{array}$ & 603 & 1,96 & 646 & 2,05 & 673 & 2,08 & 724 & 2,20 & 804 & 2,39 \\
\hline \multirow{2}{*}{4} & $\begin{array}{l}\text { Artritis } \\
\text { lainnya }\end{array}$ & \multirow{2}{*}{305} & 0,99 & 340 & 1,08 & 352 & 1,09 & 378 & 1,15 & 420 & 1,25 \\
\hline 5 & Penduduk & 30.810 & & 31.542 & & 32.291 & & 32.862 & & 33.624 & \\
\hline
\end{tabular}

Berdasarkan Tabel 3 di atas, jenis penyakit ISPA di Kecamatan Grogol persentasinya tergolong cukup tinggi > $7 \%$ dan berkecenderungan naik, sedangkan jenis penyakit dermatitis, TBC paru TBA, dan artritis masih relatif rendah.

Tabel 4: Persentasi potensi orang terkena penyakit tertentu di Kecamatan Pulomerak

\begin{tabular}{clcccccccccc}
\hline \multirow{2}{*}{ No. } & \multirow{2}{*}{ Uraian } & \multicolumn{7}{c}{ Persentasi (\%) Orang Terkena Penyakit Tertentu Di Kecamatan Pulomerak } \\
\cline { 2 - 13 } & $\mathbf{2 0 0 5}$ & $\%$ & $\mathbf{2 0 0 6}$ & $\%$ & $\mathbf{2 0 0 7}$ & $\mathbf{2 0 0 8}$ & $\mathbf{2 0}$ & $\mathbf{2 0 0 9}$ & $\%$ \\
\hline 1 & ISPA & 318 & 0,80 & 327 & 0,80 & 336 & 0,80 & 362 & 0,86 & 402 & 0,93 \\
\hline 2 & Dermatitis & 152 & 0,38 & 165 & 0,40 & 175 & 0,42 & 188 & 0,45 & 209 & 0,49 \\
\hline 3 & $\begin{array}{l}\text { TBC Paru } \\
\text { BTA }\end{array}$ & 169 & 0,42 & 178 & 0,44 & 201 & 0,48 & 216 & 0,51 & 240 & 0,56 \\
\hline 4 & $\begin{array}{l}\text { Artritis } \\
\text { lainnya }\end{array}$ & 159 & 0,40 & 172 & 0,42 & 192 & 0,46 & 206 & 0,49 & 229 & 0,53 \\
\hline 5 & Penduduk & 39.884 & & 40.831 & & 41.801 & & 42.037 & 43.012 & \\
\hline
\end{tabular}

Berdasarkan Tabel 4 di atas, jumlah penyakit di Kecamatan Pulomerak menunjukan persentasinya realatif kecil $<1 \%$ untuk jenis penyakit ISPA, dermatitis, TBC dan artritis. Meskipun jumlah penyakit ini berkecenderungan naik, namun tingkat kenaikan penyakitnya masih relatif kecil dibandingkan dengan jumlah penyakit yang terdapat di Kecamatan Ciwandan dan Citangkil.

Dengan demikian, secara deskriptif terdapat hubungan antara jumlah masyarakat yang tinggal di sekitar wilayah pesisir dengan jenis penyakit yang ditimbulkannya dan ada indikasi bahwa tumbuhnya industri-industri yang terdapat di wilayah tersebut akan berdampak pada semakin meningkatnya potensi orang terkena penyakit seperti penyakit ISPA, dermatitis, TBC, dan artritis lainnya. Oleh karena itu, semakin jauh lokasi industri, maka jumlah masyarakat yang terkena penyakit semakin rendah, hal ini disebabkan semakin jauh dari lokasi industri maka pencemaran udara semakin rendah sehingga berdampak semakin rendahnya pencemaran udara.

\subsection{Kualitas Air Laut di Wilayah Pesisir}

Logam berat adalah unsur-unsur kimia dengan bobot jenis lebih besar dari $5 \mathrm{gr} / \mathrm{cm}^{3}$, terletak di sudut kanan bawah sistem periodik, mempunyai afinitas yang tinggi terhadap unsur $S$ dan biasanya bernomor atom 22 sampai 92 dari perioda 4 sampai 7. Sebagian logam berat seperti timbal $(\mathrm{Pb})$, kadmium $(\mathrm{Cd})$, dan merkuri $(\mathrm{Hg})$ merupakan zat pencemar yang berbahaya. Afinitas yang tinggi terhadap unsur $S$ menyebabkan logam ini menyerang ikatan 
belerang dalam enzim, sehingga enzim bersangkutan menjadi tak aktif. Gugus karboksilat $(-\mathrm{COOH})$ dan amina $\left(-\mathrm{NH}_{2}\right)$ juga bereaksi dengan logam berat. Kadmium, timbal, dan tembaga terikat pada sel-sel membran yang menghambat proses transformasi melalui dinding sel. Logam berat juga mengendapkan senyawa fosfat biologis atau mengkatalis penguraiannya (Darmono. 2006). Tabel 5 ini merupakan kualitas air laut di wilayah pesisir Cilegon.

Berdasarkan Tabel 5 di lampiran menunjukkan kualitas air laut pada mengambilan sampel parameter-parameter pada kondisi air laut dinamis, sehingga sulit untuk terdeteksi dengan baik. Walaupun demikian kandungan logam berat di dalam air tidak terdeteksi, namun kandungan logam berat di dalam sedimen cukup tinggi, begitupun kandungan logam berat pada biota air terutama biota air yang bersifat menetap seperti kerang-kerangan. Rendahnya kandungan berat pada air disebabkan pada air disebabkan oleh tingginya flushing yang terjadi di wilayah pesisir dan sifat logam berat tersebut mempunyai densitas lebih dari 5, sehingga logam berat akan cenderung mengendap ke dasar perairan (Riani,
E., S.H, et al. 2004). Hal ini sesuai pendapat Law EA pada tahun 1981 menyatakan bahwa terjadinya peningkatan sumber logam berat, namun konsentrasi dalam air dapat berubah setiap saat, karena adanya berbagai macam proses yang dialami oleh senyawa tersebut selama dalam kolom air (Law. 1981). Berdasarkan hal tersebut, maka dapat dipahami jika kandungan logam berat pada air laut semuanya tidak terdeteksi. Meski demikian tercatat laporan Dinas Pertanian Kota Cilegon dalam 4 tahun terakhir rata-rata hasil pertanian (penangkapan ikan) \pm 1.103 ton/tahun, hal tersebut tidak seimbāng dengan konsumsi masyarakat untuk kebutuhan ikan lebih dari angka tersebut.

\subsection{Baku Mutu Logam Berat di Pesisir}

Untuk menentukan baku mutu logam berat di wilayah pesisir menggunakan sampel biota air yaitu kerang-kerangan dan ikan. Menurut Salim, dkk (2008), untuk menentukan konsentrasi logam berat dapat dilakukan pada sedimen dan organ tubuh pada kerang-kerangan. Tabel 6 menyajikan logam berat pada sedimen.

Tabel 6: Logam berat pada sedimen

\begin{tabular}{clcc}
\hline No. & $\begin{array}{c}\text { Logam berat } \\
\text { pada sedimen }\end{array}$ & $\begin{array}{c}\text { Konsentrasi } \\
(\mathbf{p p m})\end{array}$ & $\begin{array}{c}\text { Baku Mutu } \\
\text { (SEPA)(ppm) }\end{array}$ \\
\hline 1 & Timbal $(\mathrm{Pb})$ & 11,05 & 0,0014 \\
\hline 2 & Kadmium $(\mathrm{Cd})$ & 10,24 & 0,02 \\
\hline 3 & Crom $(\mathrm{Cr})$ & 0,73 & 0,07 \\
\hline 4 & Merkuri $(\mathrm{Hg})$ & 8,30 & $<0,05$ \\
\hline
\end{tabular}

Berdasarkan Tabel 6 di atas, kandungan logam berat pada sedimen memperlihatkan konsentrasi yang cukup tinggi, bila dibandingkan dengan ketentuan dari yang dikeluarkan oleh swedian environmental protection agence (SEPA) terutama pada kandungan logam berat kadmium (Cd) mencapai 0,02 ppm dan merkuri $(\mathrm{Hg})<0,05 \mathrm{ppm}$. Dari analisis hasil laboratorium memperlihatkan bahwa konsentrasi timbal $(\mathrm{Pb})$ pada sedimen mencapai 11,05 ppm. Kadmium (Cd) pada sedimen mencapai 10 ppm, Crom (Cr) pada sedimen mencapai $0,73 \mathrm{ppm}$ dan merkuri ( $\mathrm{Hg})$ pada sedimen mencapai 8,30 ppm. Kondisi ini memperlihatkan bahwa sumbangan dari limbah industri di wilayah pesisir Kota Cilegon cukup tinggi. Dan logam berat yang berasal dari limbah industri logam yang mengendap dan terakumulasi di dasar perairan pesisir. Hal ini sesuai dengan pendapat environmental protection agence (APE) tahun 1973 yang menyatakan bahwa zat pencemar seperti logam berat akan masuk ke dalam ekosisitem laut dan melalui proses fisika kimia akan mengakibatkan logam berat mengendap di dasar air. Demikian juga hasil penelitian yang pernah dilakukan oleh beberapa peneliti tentang hasil analisis rata-rata kadar logam berat di perairan pesisir Banten (Merak, Cilegon dan Anyer) yaitu logam berat $\mathrm{Pb}$ $=11,15 \mathrm{ppm}, \mathrm{Cd}=0,06 \mathrm{ppm}, \mathrm{Zn}=29,63 \mathrm{ppm}, \mathrm{Ni}$ $=5,28 \mathrm{ppm}$, dan $\mathrm{Cu}=6,78 \mathrm{ppm}$ ) dalam sedimen (Rochyatun, E., Lestari, A. Rozak. 2005). Sedangkan hasil penelitian yang penulis teliti ditunjukkan pada kandungan logam berat organ tubuh kerang-kerangan seperti disajikan pada Tabel 7 .

Tabel 7: Kandungan logam berat pada Organ tubuh kerang-kerangan

\begin{tabular}{clcc}
\hline No. & Jenis logam berat & $\begin{array}{c}\text { Konsentrasi pada Insang } \\
(\mathbf{p p m})\end{array}$ & $\begin{array}{c}\text { Konsentrasi pada Hati } \\
\text { (ppm) }\end{array}$ \\
\hline 1 & Timbal $(\mathrm{Pb})$ & 87 & 97 \\
\hline 2 & Kadmium $(\mathrm{Cd})$ & 69 & 171 \\
\hline 3 & Crom $(\mathrm{Cr})$ & 13,3 & 75,64 \\
\hline 4 & Merkuri $(\mathrm{Hg})$ & 69 & 121,52 \\
\hline
\end{tabular}


Berdasarkan Tabel 7 di atas, berbeda dengan kandungan logam berat pada air dan sedimen, kandungan logam berat pada kerangkerangan yang siap dikonsumsi, kandungan beratnya sangat tinggi. Dalam hal ini konsentrasi $\mathrm{Pb}$ pada insang mencapai 87 ppm, sedangkan pada hati(hepatopankreas) mencapai 97 ppm. Konsentrasi Cd pada insang mencapai 69 ppm, sedangkan pada hati (hepatopankreas) mencapai 171 ppm. Konsentarasi Cr pada insang mencapai 13,3 ppm, sedangkan pada hati (hepatopankreas) mencapai 75,64 ppm. Konsentrasi $\mathrm{Hg}$ pada insang mencapai 69 ppm, sedangkan pada hati (hepatopankreas) mencapai 121,52 ppm. Konsentarasi tersebut terjadi karena adanya akumulasi logam berat pada biota air. Hal ini sesuai dengan pernyataan EPA 1973 yang menyatakan bahwa logam berat yang masuk ke lingkungan laut akan dipekatkan melalui proses biologis, karena logam berat tersebut diserap oleh biota air terutama yang bersifat menetap seperti kerang-kerangan dan selanjutnya mengalami pemekatan di dalam kerang-kerangan tersebut. DEmikian juga pendapat lain yang menyatakan bahwa logam berat yang terdapat pada ekosistem perairan akan mengalami proses pemekatan dengan melalui proses makan memakan (biomagnifikasi) (Horiguchi.T, et al. 2006).

\section{KESIMPULAN}

Berdasarkan hasil penelitian dan pembahasan yang telah diuraikan di atas, maka dapat disimpulkan sebagai berikut:

a. Kesehatan masyarakat pada penduduk yang tinggal dipemukiman wilayah pesisir di empat Kecamatan Ciwandan, Citangkil, Grogol, dan Pulomerak berkecenderungan mengalami penyakit ISPA, bahkan jenis penyakit penduduk tersebut dapat mengalami kenaikan jumlah penyakit ISPA, mengingat pada wilayah ini banyak berdiri industri menengah hingga industri berat.

b. Walaupun limbah industri masuk pada kriteria limbah B3, namun tidak mengakibatkan buruknya kualitas air laut di wilayah pesisir Cilegon sehingga masih memenuhi batas aman dan belum melewati baku mutu air laut.

c. Konsentarsi logam berat dalam air tidak terdeteksi, tetapi konsentrasi pada sedimen dan kerang-kerangan cukup tinggi yakni $\mathrm{Pb}$ pada insang mencapai 87 ppm, sedangkan pada hati (hepatopankreas) mencapai 97 ppm. Konsentrasi Cd pada insang mencapai 69 ppm, sedangkan pada hati mencapai 171 ppm. Konsentarasi $\mathrm{Cr}$ pada insang mencapai 13,3 ppm, sedangkan pada hati mencapai 75,64 ppm. Konsentrasi $\mathrm{Hg}$ pada insang mencapai 69 ppm, sedangkan pada hati mencapai 121,52 ppm.

\section{DAFTAR PUSTAKA}

1. Clark, J.R. 1992. Integrated Management of Coastal Zones. FAO Fisheries Technical Paper No 327. Rome.Italy.

2. Dahuri, $\mathrm{R}$ 1998. Kebutuhan Riset untuk Mendukung Implementasi Pengelolaan Sumberdaya Pesisir dan Lautan Secara Terpadu. Jurnal Pesisir dan Lautan: Indonesian Journal of Coastal and Marine Resources. No ISSN: 14107821 . Vol. 1 No. 2 1998. IPB. Bogor.

3. Darmono. 2006. Lingkungan Hidup dan Pencemaran: Hubungan dengan Toksikologi Senyawa Logam. UI Press. Jakarta.

4. Rochyatun, E., Lestari, A. Rozak. 2005. Kualitas Lingkungan Perairan Banten dan Sekitarnya Ditinjau dari Kondisi Logam Berat. Jurnal Oseanologi dan Limnologi di Indonesia. ISSN: 0125-9830 No. 38: 23 - 46.

5. Gaskin, J.W., R.B. Brobst, W. P. Miller, E.W. Tollner. 2003. Long-Term Biosolids Application Effects on Metal Concentration in oils and Bermudagrass Forage. Journal of Environmental Quality 32:146-152

6. Horiguchi.T, M. Kojima, F. Hamada, A. Kajiwaha, H. Shiraishi, M. Morita and $\mathrm{H}$. Shimizu. 2006. Impact Tributiltin and Tripeniltin on Evory Shell (Babylonia Japonika Population). Environmental Health Prospective. Vo. 114 Suplement.

7. [Law]. 1981. Law EA 1981 Aquatic Pollution. John Wiley and Sons. New York.

8. Riani, E., S.H. Sutjahjo, dan Firmansyah. 2004. Analisa Beban Pencemaran dan Kapasitas Asimilasi Teluk Jakarta. Kerjasama LPPM IPB dengan Pemprov. DKI Jakarta.

9. Sukreeyapongse, O, P.E. Holm, B.W. Strobel, S. Panichasakpatana, J. Magid, H.C.B. Hansen. 2002. pH-Dependent Release of Cadmium, Copper, and Lead from Natural and Sludge Amended Soil. Journal Environmental. Quality, 31:19011909.

10. Suratmo, F.G. 2002. Analisis Mengenai Dampak Lingkungan. Gadjah Mada University Press. Yogyakarta. 
Tabel 5. Kualitas air laut di wilayah pesisir Cilegon

\begin{tabular}{|c|c|c|c|c|c|c|c|c|c|c|c|c|c|c|c|}
\hline \multirow{3}{*}{ No. } & \multirow{3}{*}{ PARAMETER } & \multirow{3}{*}{ SATUAN } & \multirow{3}{*}{$\begin{array}{l}\text { BAKU } \\
\text { MUTU }\end{array}$} & \multicolumn{12}{|c|}{ HASIL UJI LABOTARIUM TIAP KECAMATAN } \\
\hline & & & & \multicolumn{3}{|c|}{ CIWANDAN } & \multicolumn{3}{|c|}{ CITANGKIL } & \multicolumn{3}{|c|}{ PULOMERAK } & \multicolumn{3}{|c|}{ GROGOL } \\
\hline & & & & 2007 & 2008 & 2009 & 2007 & 2008 & 2009 & 2007 & 2008 & 2009 & 2007 & 2008 & 2009 \\
\hline & \multicolumn{15}{|l|}{ A. FISIKA } \\
\hline 1 & $\mathrm{Bau}$ & - & $\begin{array}{c}\text { Tdk } \\
\text { berbau }\end{array}$ & $\begin{array}{c}\text { Tdk } \\
\text { berbau }\end{array}$ & $\begin{array}{c}\text { Tdk } \\
\text { berbau }\end{array}$ & $\begin{array}{c}\text { Tdk } \\
\text { berbau }\end{array}$ & $\begin{array}{c}\text { Tdk } \\
\text { berbau }\end{array}$ & $\begin{array}{c}\text { Tdk } \\
\text { berbau }\end{array}$ & $\begin{array}{c}\text { Tdk } \\
\text { berbau }\end{array}$ & $\begin{array}{c}\text { Tdk } \\
\text { berbau }\end{array}$ & $\begin{array}{c}\text { Tdk } \\
\text { berbau }\end{array}$ & $\begin{array}{c}\text { Tdk } \\
\text { berbau }\end{array}$ & $\begin{array}{c}\text { Tdk } \\
\text { berbau }\end{array}$ & $\begin{array}{c}\text { Tdk } \\
\text { berbau }\end{array}$ & $\begin{array}{c}\text { Tdk } \\
\text { berbau }\end{array}$ \\
\hline 2 & Kecerahan & Meter & $>3$ & 3,25 & 3,0 & 3,0 & 3,0 & 3,5 & 3,0 & 3,0 & 3,0 & 3,0 & 3,0 & 3,0 & 3,0 \\
\hline 3 & Zat padat tersuspensi & $\mathrm{Mg} / \mathrm{l}$ & 80 & 5 & 3 & 1 & 5 & 5 & 1 & 12 & 4 & 5 & 12 & 7 & 2 \\
\hline 4 & Suhu & ${ }^{\circ} \mathrm{C}$ & Alami & 31,2 & 29,6 & 30,0 & 30,8 & 30,0 & 29,7 & 30,0 & 29,7 & 30,1 & 30,0 & 31,9 & 30,0 \\
\hline 5 & Lapisan Minyak & - & Nihil & Negatif & Negatif & Negatif & Negatif & Negatif & Negatif & Negatif & Negatif & Negatif & Negatif & Negatif & Negatif \\
\hline \multirow[t]{2}{*}{6} & Sampah & - & Nihil & Negatif & Negatif & Negatif & Negatif & Negatif & Negatif & Negatif & Negatif & Negatif & Negatif & Negatif & Negatif \\
\hline & \multicolumn{15}{|l|}{ B. KIMIA } \\
\hline 1 & $\mathrm{pH}$ & - & $6,5-8,5$ & 7,85 & 8,09 & 7,70 & 7,89 & 8,10 & 7,80 & 8,4 & 7,87 & 7,40 & 8,5 & 7,93 & 7,70 \\
\hline 2 & Salinitas & $\%$ & Alami & 33,7 & 33,7 & 32,4 & 33,3 & 32,4 & 32,32 & 33,2 & 32,0 & 32,4 & 33,3 & 32,4 & 32,2 \\
\hline 3 & Amonia Total $\left(\mathrm{NH}_{3}-\mathrm{N}\right)$ & $\mathrm{mg} / \mathrm{l}$ & 0,3 & 0,02 & $<0,01$ & $<0,01$ & 0,02 & $<0,01$ & $<0,01$ & 0,05 & $<0,01$ & $<0,01$ & 0,01 & $<0,01$ & $<0,01$ \\
\hline 4 & Sulfida $\left(\mathrm{H}_{2} \mathrm{~S}\right)$ & $\mathrm{mg} / \mathrm{l}$ & 0,03 & $<0,002$ & $<0,002$ & $<0,002$ & $<0,002$ & $<0,002$ & $<0,002$ & $<0,002$ & $<0,002$ & $<0,002$ & $<0,002$ & $<0,002$ & $<0,002$ \\
\hline 5 & Fenol & $\mathrm{mg} / \mathrm{l}$ & 0,002 & $<0,001$ & $<0,001$ & $<0,001$ & $<0,001$ & $<0,001$ & $<0,001$ & $<0,001$ & $<0,001$ & $<0,001$ & $<0,001$ & $<0,001$ & $<0,001$ \\
\hline 6 & Surfactan Anion & $\mathrm{mg} / \mathrm{l}$ & 1,0 & 0,25 & $<0,01$ & $<0,01$ & 0,23 & $<0,01$ & $<0,01$ & 0,21 & $<0,01$ & $<0,01$ & 0,23 & $<0,01$ & $<0,01$ \\
\hline 7 & Minyak dan Lemak & $\mathrm{mg} / \mathrm{l}$ & 5,0 & $<0,2$ & $<0,2$ & $<0,2$ & $<0,2$ & $<0,2$ & $<0,2$ & $<0,2$ & $<0,2$ & $<0,2$ & $<0,2$ & $<0,2$ & $<0,2$ \\
\hline 8 & Air Raksa (Hg) & $\mathrm{mg} / \mathrm{l}$ & 0,003 & $<0,0005$ & $<0,0005$ & $<0,0005$ & $<0,0005$ & $<0,0005$ & $<0,0005$ & $<0,0005$ & $<0,0005$ & $<0,0005$ & $<0,0005$ & $<0,0005$ & $<0,0005$ \\
\hline 9 & Kadmium (Cd) & $\mathrm{mg} / \mathrm{l}$ & 0,01 & $<0,0005$ & $<0,0005$ & $<0,0005$ & $<0,0005$ & $<0,0005$ & $<0,0005$ & $<0,0005$ & $<0,0005$ & $<0,0005$ & $<0,0005$ & $<0,0005$ & $<0,0005$ \\
\hline 10 & Tembaga (Cu) & $\mathrm{mg} / \mathrm{l}$ & 0,05 & $<0,0005$ & $<0,0005$ & $<0,0005$ & $<0,0005$ & $<0,0005$ & $<0,0005$ & $<0,0005$ & $<0,0005$ & $<0,0005$ & $<0,0005$ & $<0,0005$ & $<0,0005$ \\
\hline 11 & Timbal $(\mathrm{Pb})$ & $\mathrm{mg} / \mathrm{l}$ & 0,05 & $<0,005$ & $<0,005$ & $<0,005$ & $<0,005$ & $<0,005$ & $<0,005$ & $<0,005$ & $<0,005$ & $<0,005$ & $<0,005$ & $<0,005$ & $<0,005$ \\
\hline \multirow[t]{2}{*}{12} & Seng $(Z n)$ & $\mathrm{mg} / \mathrm{l}$ & 0,1 & 0,332 & 0,0284 & 0,0208 & 0,0290 & 0,0284 & 0,0211 & 0,332 & 0,0287 & 0,0201 & 0,333 & 0,0265 & 0,0212 \\
\hline & C. MIKROBIOLOGI & & & & & & & & & & & & & & \\
\hline 1 & kolifrom Total & MPN/100 ml & 1.000 & 0 & 0 & 0 & 0 & 0 & 0 & 0 & 0 & 0 & 0 & 0 & 0 \\
\hline
\end{tabular}

